\title{
Evaluating phytoplankton dynamics in the Newport River estuary (North Carolina, USA) by HPLC-derived pigment profiles
}

\author{
Patricia A. Tester ${ }^{1, *}$, Mark E. Geesey ${ }^{1}$, Chunzhi Guo ${ }^{1}$, Hans W. Paerl ${ }^{2}$, David F. Millie ${ }^{3}$ \\ ${ }^{1}$ National Marine Fisheries Service, Southeast Fisheries Science Center, NOAA, Beaufort Laboratory, Beaufort, \\ North Carolina 28516, USA \\ ${ }^{2}$ Institute of Marine Sciences, University of North Carolina at Chapel Hill, 3431 Arendell Street, Morehead City, \\ North Carolina 28557, USA \\ ${ }^{3}$ Agricultural Research Service, Southern Regional Research Center, U.S. Department of Agriculture, \\ 1100 Robert E. Lee Boulevard, New Orleans, Louisiana, 70124 USA \\ and Department of Biological Sciences, Loyola University, 6363 St. Charles Avenue, New Orleans, Louisiana 70118, USA
}

\begin{abstract}
The composition and dynamics of phytoplankton assemblages during the spring bloom in a shallow, coastal-plain estuary were characterized by high-performance liquid chromatography (HPLC)-derived pigment profiles. From mid-February through the first week in June 1991, samples were collected twice weekly at 2 sites within the Newport River estuary, North Carolina, USA. Pigment profiles, reflecting phytoplankton assemblages dominated by diatoms, dinoflagellates, prymnesiophytes, cryptophytes, and chlorophytes, were compared to phytoplankton cell counts. There were significant ( $\mathrm{p} \leq 0.0005, \mathrm{r}^{2}=0.49$ to 0.63 ) relationships between the taxon-specific pigment concentrations and the taxon-specific cell numbers. HPLC-determined chlorophyll (chl) a biomass corresponded with the sum of the taxon-specific chl a biomass $\left(p \leq 0.001, r^{2}=0.95\right)$. Each taxon-specific biomass was calculated based on chl a:accessory pigment ratios determined by regression analyses. Chl a biomass was also measured fluorometrically and compared with the HPLC results. Fluorometric analysis underestimated biomass when prymnesiophytes, cryptophytes, and chlorophytes dominated the phytoplankton. Despite the inherent environmental variability of the estuarine sampling location, HPLC-derived pigment profiles did provide division-level phylogenetic assessment of large, short-term changes in the phytoplankton composition and detected assemblage responses to event-scale perturbation effects (e.g. precipitation, wind). These results demonstrate that even in highly variable environments HPLCbased pigment analysis is a valuable tool, providing complementary information to the traditional methodology of cell counting
\end{abstract}

KEY WORDS: Phytoplankton · Pigments HPLC

\section{INTRODUCTION}

Phytoplankton size structure, species composition, and temporal dynamics are important determinants of trophic interactions in marine ecosystems. Phytoplankton identification and enumeration are typically obtained through microscopic examination which requires a high level of taxonomic skill and may take considerable time. Small cells $(<5 \mu \mathrm{m})$, particularly flagellates, can be

•E-mail: ptester@hatteras.bea.nmfs.gov especially difficult to identify and are usually counted as a group by epifluorescence microscopy.

Alternatively, phytoplankton phylogenetic groups may be characterized based on the presence or absence of diagnostic pigments. Chlorophyll (chl) and carotenoid pigments, either singly or in combination, have been used successfully for chemosystematic identification of phytoplankton in oceanic waters (e.g. Jeffrey et al. 1975, Gieskes \& Kraay 1983, Guillard et al. 1985, 1991, Wright \& Jeffrey 1987, Goericke \& Repeta 1992). Although pigments may vary among 
cells within a taxon or between taxa, the abundances of the diagnostic pigments generally reflect the major distributions of phytoplankton to the division or class level. High-performance liquid chromatography (HPLC) has proven to be an effective technique for separating and quantifying lipophilic pigments in both monotypic and mixed algal samples. As such, HPLC-based pigment analyses can accurately characterize phytoplankton phylogenetic groups and changes in community composition, as well as provide information concerning phytoplankton physiological status and trophic interaction (for a review, see Millie et al. 1993).

The characterization of pico- and nanophytoplankton assemblages in stable, open ocean systems by HPLC-based pigment analyses is becoming increasingly routine (e.g. Gieskes \& Kraay 1986a, b, Bidigare et al. 1990, Everitt et al. 1990,

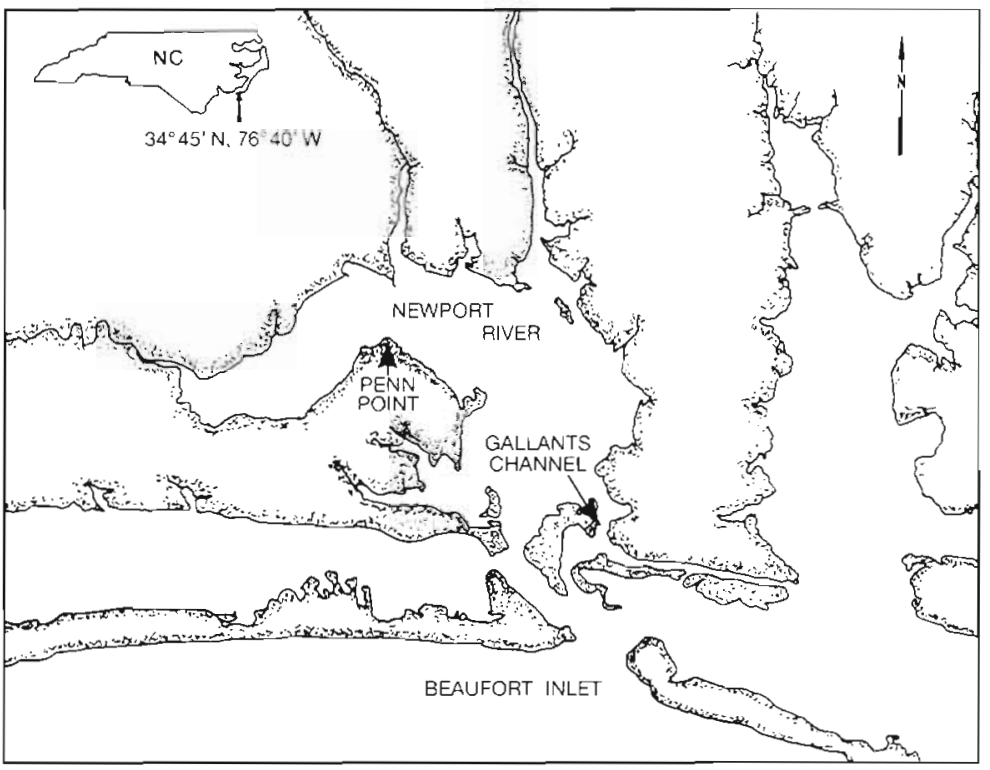

Fig. 1. Location of study sites in the Newport River estuary, North Carolina, USA
Veldhuis \& Kraay 1990, Bartow et al. 1993). However, this technique has rarely been used for characterizing phytoplankton assemblages within highly variable marine environments, such as coastal waters or estuaries (Klein \& Sournia 1987, Roy 1989). Further, no studies of marine or estuarine systems have compared diagnostic pigment composition with comprehensive cell counts of phytoplankton, particularly over a seasonal time scale. An investigation of a freshwater lake by Wilhelm et al. (1991) served as a catalyst for this study (see also Soma et al. 1993).

The objective of this research was to evaluate the utility of HPLC-based pigment analyses for detecting changes in species composition of estuarine phytoplankton. Sampling sites were chosen in a shallow, coastal-plain estuary to ensure that spatial and environmental variability would be represented. The spring bloom period (February to June) was selected to provided a strong seasonal signal when both the phytoplankton species composition and biomass were changing rapidly (Thayer 1971).

\section{METHODS}

The Newport River estuary $\left(34^{\circ} 45^{\prime} \mathrm{N}, 76^{\circ} 40^{\prime} \mathrm{W}\right)$ is a shallow, tide-flushed system in the Outer Banks region of North Carolina, USA (Fig. 1). This estuary drains an agricultural, forest, and pocosin watershed of approximately $310 \mathrm{~km}^{2}$ and receives average monthly rainfall of 7.9 to $11.2 \mathrm{~cm}$ (based on $10 \mathrm{yr}$ average) between February and June (Kirby-Smith \& Costlow 1989). The main body of the estuary extends
$15 \mathrm{~km}$ in length and is approximately 4 to $5 \mathrm{~km}$ in width with a mean depth of $1 \mathrm{~m}$. Nearly one-half of its water volume moves in and out with each tidal cycle (Kirby-Smith \& Costlow 1989) and the estimated flushing time ranges between 4.5 and $9.6 \mathrm{~d}$ (Jennings et al. 1970).

Sampling sites were established within Gallants Channel and at Penn Point (Fig. 1). The Gallants Channel site (approx. $4 \mathrm{~m}$ depth) was dominated, even at low tide, by the influx of high salinity coastal water through Beaufort Inlet (Fig. 1). The Penn Point site was located in the shallow (1 to $2 \mathrm{~m}$ ), middle section of the estuary and was especially subject to the influence of wind mixing and terrestrial runoff.

From 14 February to 6 June 1991, surface water samples $(n=58)$ were collected at each site twice weekly, 0 to 2 h prior to daytime low tide. Phytoplankton samples were preserved with Utermöhl's solution, concentrated in Utermöhl settling chambers, and enumerated using an inverted microscope (after Lund et al. 1958). Salinity, water temperature, and general meteorological conditions were recorded at time of sampling. Continuously recorded information on wind speed, wind direction, and surface water temperature at Gallants Channel were made available by the Duke University Marine Laboratory. For lipophilic pigment analyses, 200 to $1500 \mathrm{ml}$ of water was filtered onto Whatman GF/F filters. The filters were immediately frozen and stored $(<30 \mathrm{~d})$ at $-20^{\circ} \mathrm{C}$ until analysed. Frozen filters were placed in $2 \mathrm{ml}$ of $100 \%$ acetone, sonicated, and extracted in darkness overnight at $4^{\circ} \mathrm{C}$. Pigment extracts were centrifuged and the supernatants mixed with an ion-pairing agent (after Man- 
toura \& Llewellyn 1983). A volume of $200 \mu \mathrm{l}$ of filtered mixture was injected directly into an Spectra-Physics Model 8800 HPLC equipped with a $250 \times 4.6 \mathrm{~mm}$ ODS18 Altex Ultrasphere column and a photodiode array detector The mobile phases followed those of Mantoura \& Llewellyn (1983) or Wright et al. (1991) at flow rates of 1 or $1.5 \mathrm{ml} \mathrm{min}{ }^{-1}$ Pigment peaks were identified and quantified by comparison of retention times and absorption spectra to those of crystalline standards, including chl $a$ and $b$ (Sigma Chemical Company), and fucoxanthin (Hoffman-LaRoche \& Company). Peridinin, 19'-hexanoyloxyfucoxanthin and alloxanthin were extracted from phytoplankton cultures (see Wright et al. 1991) and quantified using the appropriate extinction coefficients (from Mantoura \& Llewellyn 1983).

Additionally, chl a was assayed using fluorometric analyses for comparisons with HPLC pigment analyses. A volume of 100 to $1000 \mathrm{ml}$ of sample was filtered and stored frozen as above. Chl a was extracted in 90:10 (v/v) acetone:water and measured in a Turner Designs Model 10 fluorometer. The fluorometer was calibrated with spectrophotometrically determined concentrations of chl a obtained from estuarine phytoplankton (after Parsons et al. 1984).

Multiple linear regression was used to assess the phylogenetic group-specific contribution to total chl a biomass (Gieskes \& Kraay 1983). The chl a:accessory pigment ratios were established for each phylogenetic group by the regression. Using the appropriate regression coefficients, the contribution of each phylogenetic group to the total chl a biomass was then calculated and plotted. The relative abundance of diagnostic pigments was compared to the relative cell abundance for each phylogenetic group to test how well pigmentspecific biomass reflected cell counts. Relative abundance data were in percentages and were arcsinetransformed prior to statistical analysis (Sokal \& Rohlf 1969). The F-statistic was used to test the hypothesis that the slopes of the regressions were different from zero. The Student's $t$-test was used to determine the significance of the correlation coefficients. The $\mathrm{p}$-value, in the case of several comparisons, refers to the least significant relationship.

\section{RESULTS}

A total of 100 algal taxa (encompassing 89 genera and 55 species) were identified. Of the identified species $82 \%$ were diatoms. The diatoms Skeletonema sp., Leptocylindrus spp. and Chaetoceros spp. were the dominant phytoplankton at Gallants Channel where the highest standing crop $\left(22.6 \times 10^{5}\right.$ cells $\left.^{-1}\right)$ occurred on the 108th day of the year (Day 108) (Fig. 2a). Centric diatoms were approximately 3 -fold more abundant than pennate diatoms (Fig. 2a, b) with the greatest number of pennates $\left.\left(6.1 \times 10^{5} \text { cells }\right)^{-1}\right)$ between Days 80 and 1.05 (Fig. 2b). Asterionella glacialis Castr accounted for approximately $50 \%$ of the pennate standing crop. Increasing standing crop values for diatoms coincided with increasing water temperature (compare Fig. 2c and d) and increasing day length up to Day 108. Microflagellates, primarily Pyramimonas spp., Chlamydomonas spp., Chroomonas spp., and Cryptomonas spp., replaced diatoms as the dominant phytoplankton with standing crop values up to $5 \times 10^{8}$ cells $1^{-1}$ in the lower estuary between Days 118 and 149 while standing crop values for diatoms declined to less than $2 \times 10^{5}$ cells $^{-1}$ by Day 130 (Fig. 2 c; note different scale for microflagellates).

At Penn Point, pennate diatoms were approximately 1.2- to 5 -fold more abundant than centric diatoms (compare Fig. 3a and b). The greatest pennate standing crop $\left(51.6 \times 10^{5}\right.$ cells $\left.l^{-1}\right)$ occurred on Day 67 with Nitzschia spp. as the dominant genus. Centric diatoms were most abundant between Days 67 and $77(9.7 \times$ $10^{5}$ cells $\left.^{-1}{ }^{-1}\right)$ and between Days 101 and $112\left(143 \times 10^{5}\right.$ cells 1 ') with Skeletonema sp. and Cyclotella spp., respectively, as the dominant genera. After Day 127 microflagellates replaced diatoms as the major contributor to total standing crop and were most abundant (4 to $5 \times 10^{8}$ cells $1^{-1}$ ) between Days 140 and 149 (Fig. 3c, note different scale for microflagellates). At Penn Point, changes in standing crop values coincided with periods of high wind and/or precipitation with a lag time of approximately $4 \mathrm{~d}$ (Fig. 3d). At both Gallants Channel and Penn Point changes in chl a concentrations reflected changes in total phytoplankton standing crop (Figs. $2 c \& 3 c$ ). In addition to chl $a, 5$ major accessory pigments were quantified, including peridinin, fucoxanthin, 19'-hexanoyloxyfucoxanthin, alloxanthin and chl b. HPLC-based pigment analyses reflected the shift from diatom to microflagellate dominance at both sampling sites (Fig. 4a, c). At Gallants Channel, increasing concentrations of fucoxanthin (indicative of diatoms) corresponded with increasing diatom standing crop (compare Figs. 2c \& 4a) reaching the greatest value on Day 108. After Day 118, concentrations of $19^{\prime}$-hexanoyloxyfucoxanthin, alloxanthin, and chl $b$ (indicative of the prymnesiophytes, cryptophytes, and chlorophytes, respectively) coincided with increasing microflagellate standing crop. Low peridinin concentrations, observed throughout the entire study, were indicative of and consistent with low numbers of dinoflagellates.

At the Penn Point site, fucoxanthin comprised the greatest proportion of the pigments between Days 47 and 69 (Fig. 4c). Here, peridinin was the principal pigment only at the beginning of the study period when 

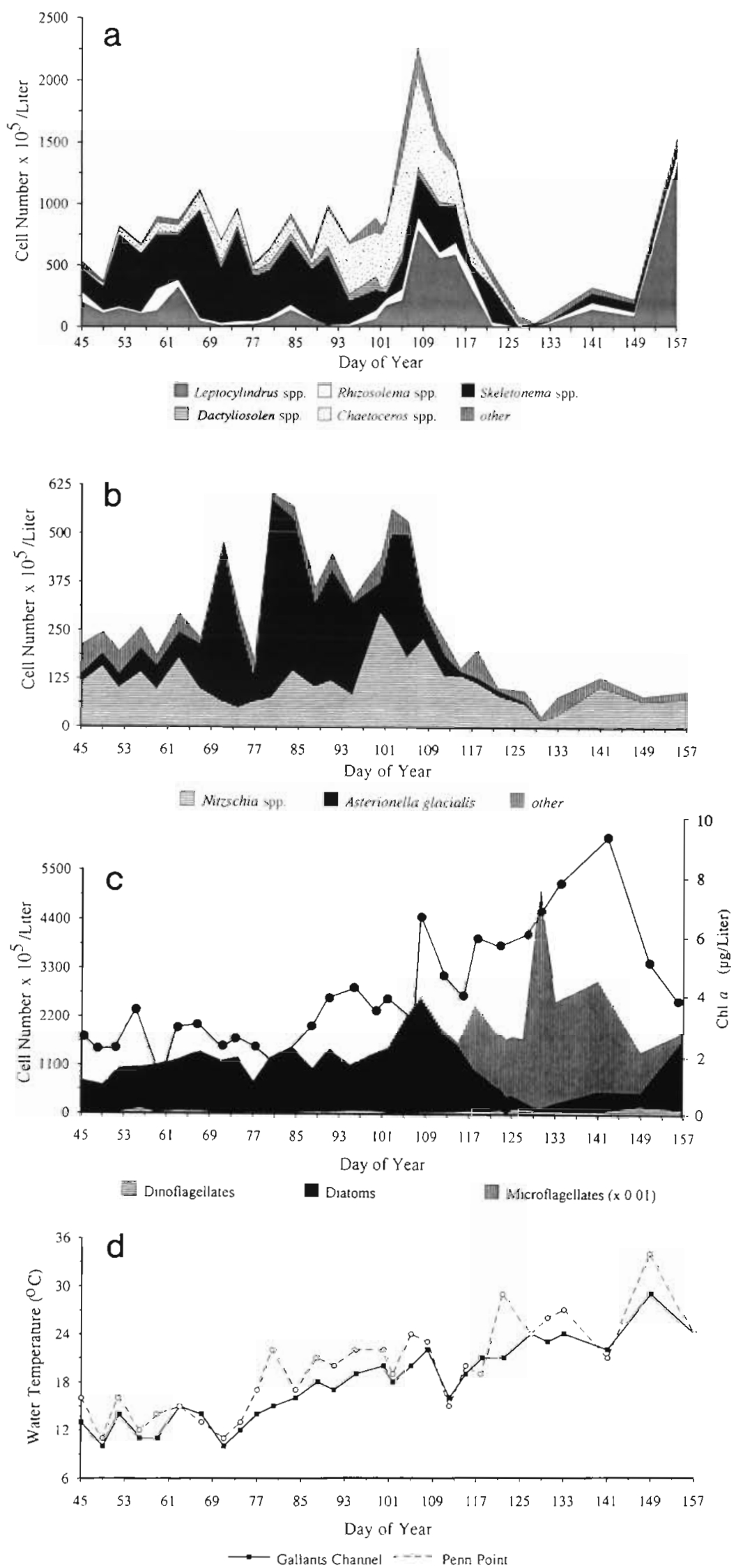

the winter bloom of Heterocapsa triquetra Ehrenberg was declining (Figs. 3c \& $4 \mathrm{c}$ ). After Day 112, the concentrations of pigments indicative of microflagellates exceeded that of fucoxanthin. This was attributable to marked increases in alloxanthin and chl $b$ and a small increase in $19^{\prime}$-hexanoyloxyfucoxanthin.

Linear relationships ( $p \leq 0.0005$ ) exist between corresponding diagnostic pigments and relative cell abundances:

$$
\begin{aligned}
\% \text { Dino }= & 8.493 \times 10^{-4} \\
& +0.9288 \% \text { Perid } \\
& \left(\mathrm{N}=21, \mathrm{r}^{2}=0.4892\right) \\
\% \text { Diat }= & 0.2284+0.9415 \% \text { Fuco } \\
& \left(\mathrm{N}=49, \mathrm{r}^{2}=0.5327\right) \\
\% \text { Flag }= & 0.2459+0.8031 \% \text { Hex } \\
& +0.9243 \% \text { Allox } \\
& +0.7664 \% \text { chl } b \\
& \left(\mathrm{~N}=49, \mathrm{r}^{2}=0.6253\right)
\end{aligned}
$$

where \%Dino, \%Diat, and \%Flag are the relative abundances of dinoflagellates, diatoms, and flagellates, and \%Perid, $\%$ Fuco, \%Hex, \%Allox and \%chl $b$ are the relative abundances of peridinin, fucoxanthin, 19'-hexanoyloxyfucoxanthin, alloxanthin, and chl $b$.

The phylogenetic, group-specific contribution to total chl a biomass was determined by a multiple linear regression equation establishing the chl a:accessory pigment ratios (i.e. the regression coefficients) for each group as follows:

$$
\begin{aligned}
\text { Chl } a= & 2.688 \text { Perid }+2.313 \text { Fuco } \\
& +1.768 \text { Hex }+3.043 \text { Allox } \\
& +6.441 \mathrm{chl} b \\
& \left(\mathrm{n}=52, \mathrm{r}^{2}=0.9570, \mathrm{p} \leq 0.0001\right)
\end{aligned}
$$

where Perid, Fuco, Hex, and Allox were concentrations of peridinin, fucoxanthin, 19'-hexanoyloxyfucoxanthin, and alloxanthin, respectively. This regression was an adequate predictor of the total chl a biomass throughout the spring and at

Fig. 2. Phytoplankton and chl a abundance at Gallants Channel from Day 45 through 156 (14 February through 6 June 1991). (a) Dominant centric diatoms; (b) dominant pennate diatoms; (c) comparison of cell abundances with total chl a biomass; and (d) surface water temperatures $\left({ }^{\circ} \mathrm{C}\right)$ at Gallants Channel and Penn Point 
both sites ( $p \leq 0.0001$ ) (Fig. 5a, b). Furthermore, the group-specific chl a biomass corresponded with the groupspecific standing crop determined from microscopic cell counts $(p \leq$ 0.0001) (compare Figs. 2c \& 4b, 3c \& $4 \mathrm{~d})$.

Concentrations of chl $a$ as determined by the fluorometric method corresponded with concentrations determined by HPLC analysis from Days 45 to 100 . However, the fluorometric method underestimated chl a concentrations when microflagellates dominated the phytoplankton (Fig. 5a, b).

\section{DISCUSSION}

HPLC-based pigment profiles accurately characterized phytoplankton abundance and phylogenetic composition during the spring bloom in the Newport River estuary. Total and group-specific chl a biomass derived from HPLC analysis reflected the total and group-specific cell counts and correspondingly more than $95 \%$ of the variability in total chl a biomass was explained by the group-specific diagnostic pigments.

HPLC-derived pigment profiles are able to reveal large, short-term changes in phytoplankton biomass. Particularly notable is the sensitivity of this technique to detect event-scale perturbations such as wind mixing and the subsequent resuspension of phytoplankton or stimulation by rainfall. An example is the shallow (1 to $2 \mathrm{~m}$ ) Penn Point site where pennate diatoms were the dominant phytoplankton. Here changes in the standing crop consistently lagged behind

Fig. 3. Phytoplankton and chl a abundance and daily mean wind speeds at Penn Point from Day 45 through 156 (14 February through 6 June 1991). (a) Dominant centric diatoms; (b) dominant pennate diatoms; (c) comparison of cell abundances with total chl a biomass; and (d) mean surface wind speeds $\left(>13 \mathrm{~km} \mathrm{~h}^{-1}\right.$ ) near Penn Point

Arrows indicate precipitation of $>5 \mathrm{~cm}$
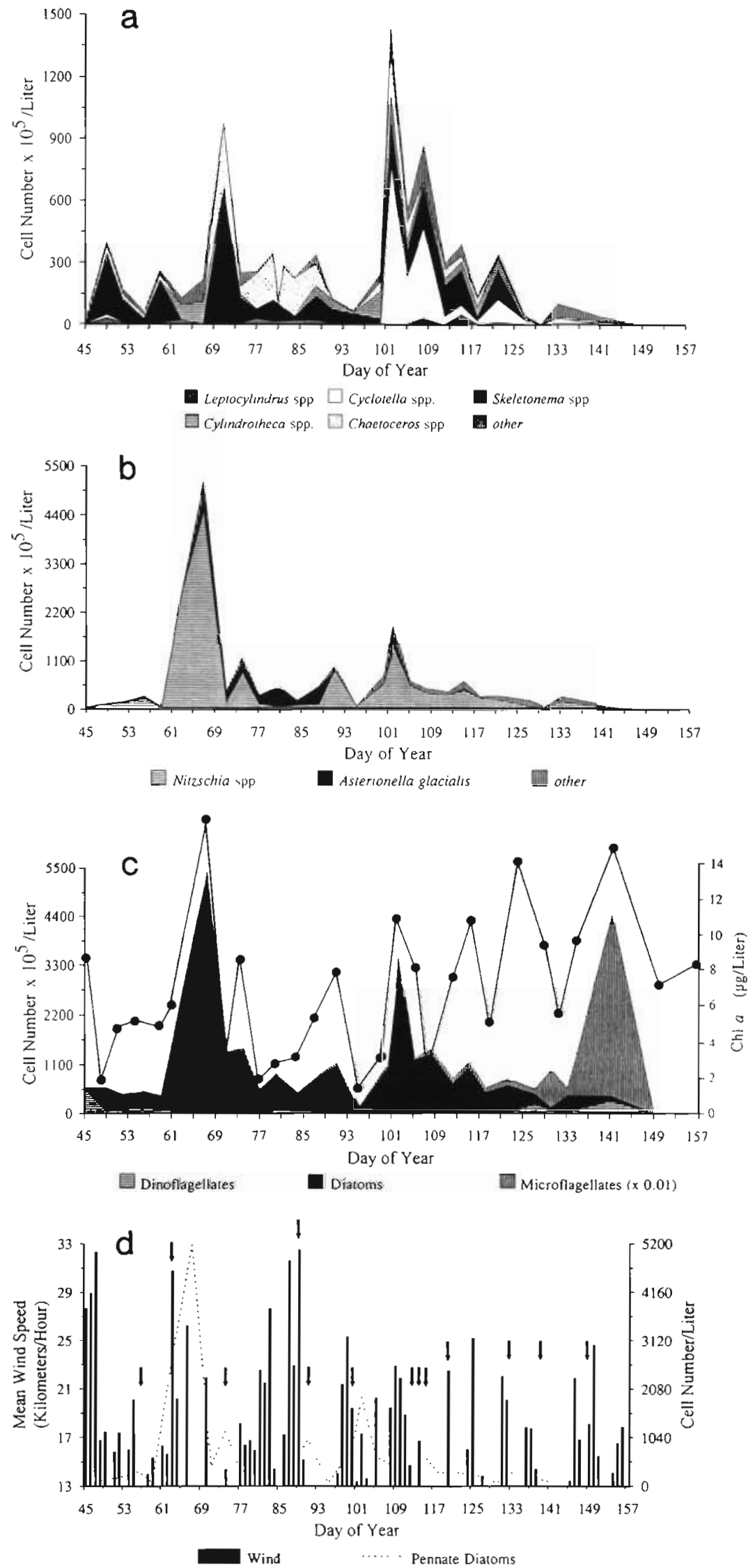

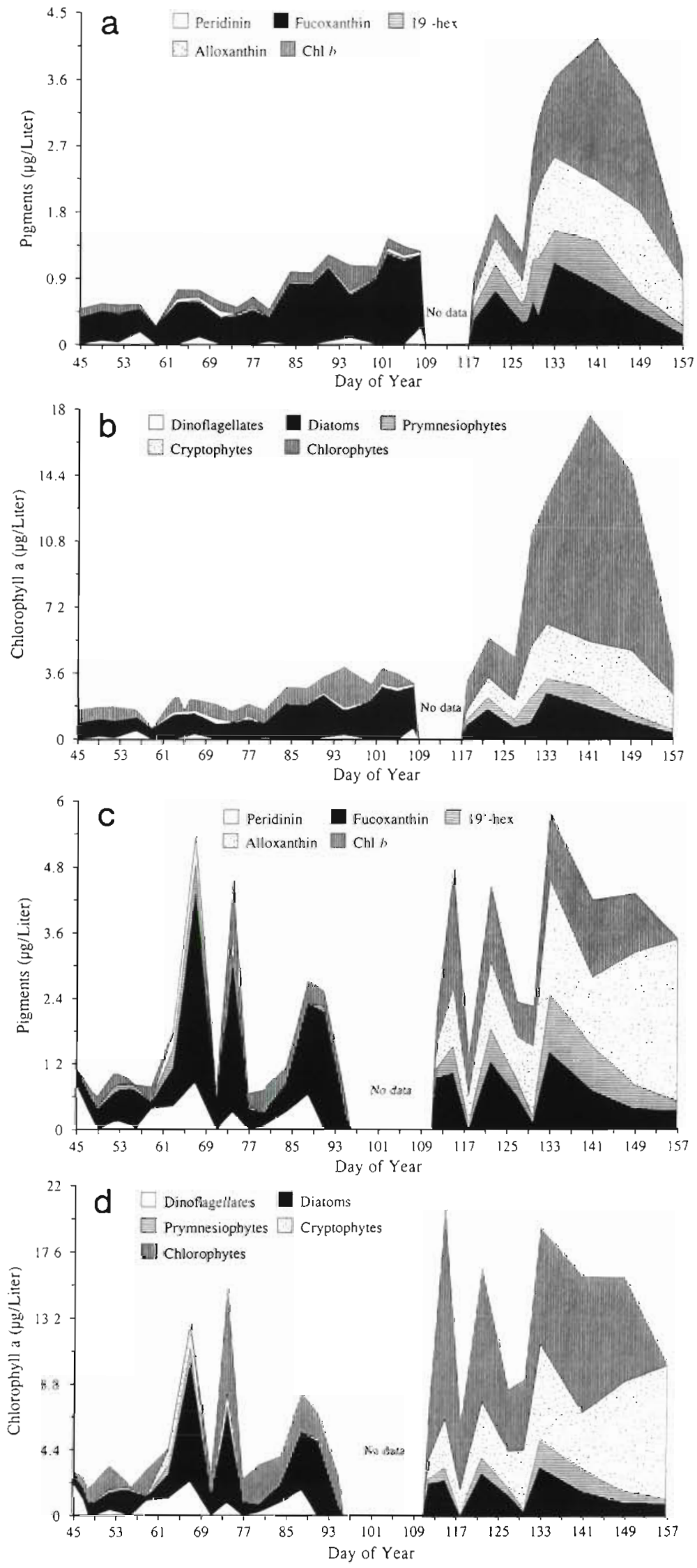

weather events by 3 to $4 \mathrm{~d}$ and these biomass changes are distinguishable within the seasonal cycle. The observed fluctuations in fucoxanthin concentration, as well as the fucoxanthin-specific contribution to the total chl a biomass, reflect the resuspension and subsequent settling of benthic pennate diatoms in the water column at the shallow Penn Point site. In contrast, at the deeper $(4 \mathrm{~m})$ Gallants Channel site changes in phytoplankton standing crop followed seasonal changes in water temperature.

In the last stage of the spring bloom a transition from diatoms to microflagellates as the dominant phytoplankton occurred at both Gallants Channel and Penn Point. This transition was fully characterized by pigment composition changes from fucoxanthin to alloxanthin, chl $b$ and 19'-hexanoyloxyfucoxanthin (indicative of cryptophytes, chlorophytes, and prymnesiophytes, respectively). Although preservation and microscopic identification of microflagellates are difficult, HPLC-based pigment analyses were able to quantify the contribution of 3 major microflagellate groups, thereby proving effective in fingerprinting small, fragile species.

Measurements of chl $a$ by the fluorometric and HPLC methods were nearly identical until microflagellates dominated the phytoplankton assemblage (see Fig. 5a, b). From Day 115 to 149 at both Gallants Channel and Penn Point the fluorometric method underestimated chl a concentrations compared with HPLC-determined chl $a$. This is not surprising considering that large amounts of chl $b$ are known to interfere with the fluorometric determination of chl a (Gibbs 1979). Fluorometric analysis is also reported to overestimate chl $a$ when large amounts of chl $c$ are present within samples (Trees et al. 1985) but such an overestimation was not observed at either site when the chl c-containing phytoplankton were dominant.

Fig. 4. HPLC-based pigment analses: (a) phytoplankton group-specific pigments and (b) group-specific contribution to total chl a biomass in Gallants Channel. (c) Group-specific pigments and (d) group-specific contribution to total chl a biomass at Penn Point 


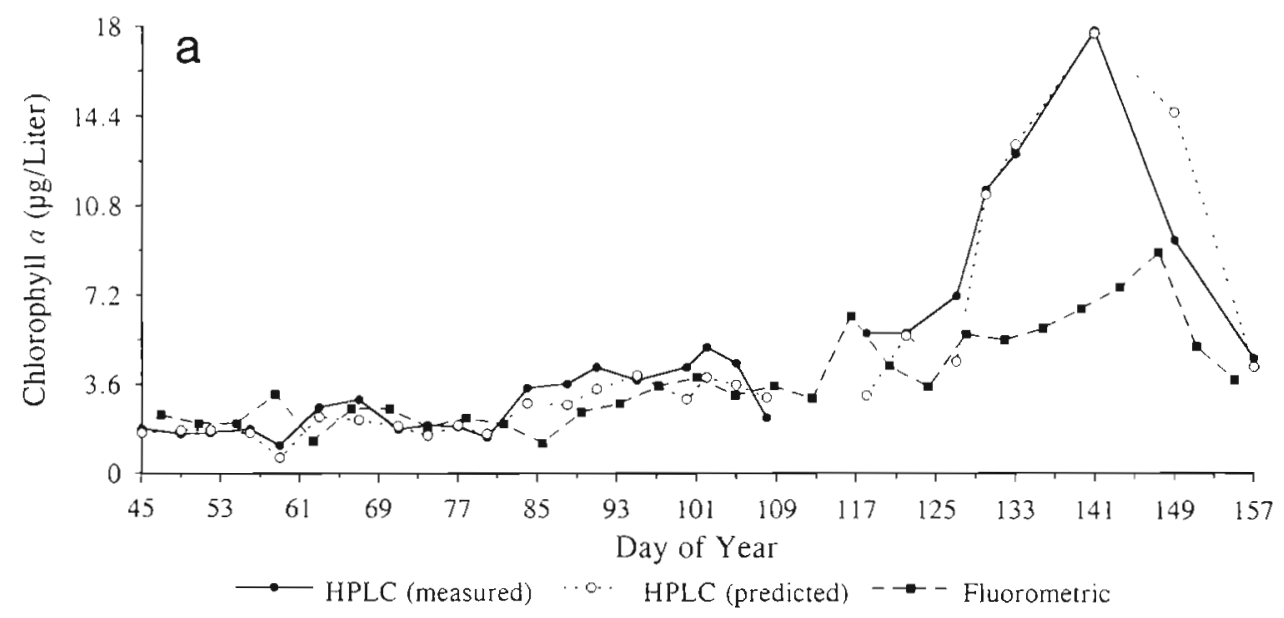

Fig. 5. Comparison of total chl a biomass determined by HPLC and fluorometric techniques and predicted by the regression equations for (a) Gallants Channel and (b) Penn Point

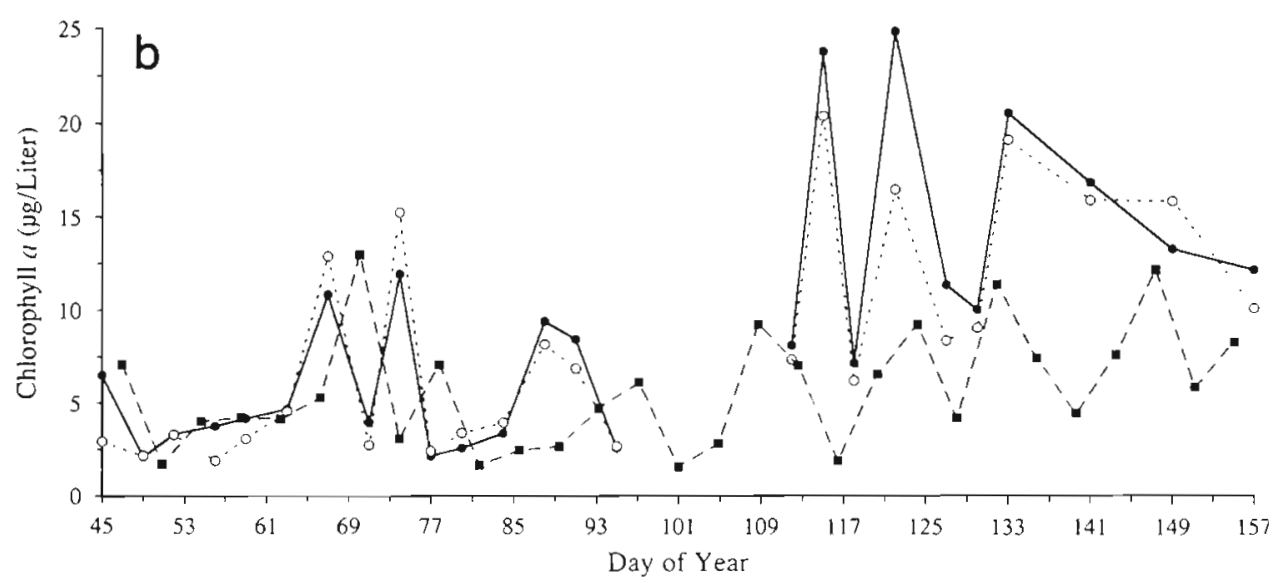

$\longrightarrow$ HPLC (measured) $\cdots \sigma$ HPLC (predicted) $\rightarrow-$ Fluorometric

Although the regressions of relative cell abundances on relative diagnostic pigments were highly significant, only 40 to $63 \%$ of the variability was explained. Part of the variability may stem from the use of distinctly different reference parameters in HPLC and cell counting analyses, as was noted by Wilhelm et al. (1991). HPLC analyses provide uniform assessments of $\mathrm{chl}$ a and other diagnostic pigments, whereas cell counts are based on static, morphological characteristics and the resulting biomass estimates are affected by the physiological conditions (live vs dead) and cell size.

Also, the assumption that the chl a:accessory pigment ratios were similar at both sites and constant over the entire sampling period merits scrutiny. Since chl a and accessory pigment contents of phytoplankton may vary within each phylogenetic group and are dependent upon photoacclimation state (Jeffrey \& Vesk 1978, Falkowski \& Owens 1980, Paerl et al. 1983, 1985, Millie et al. 1990) and nutritional status (Gowen et al. 1983, Ridout \& Morris 1985, Naes \& Post 1988), such fluctuations of pigment content and composition may have accounted for a portion of the unexplained variability. However, the chl a:accessory pigment ratios from this seasonal study are within the range of ratios for other field samples from both marine and freshwater systems (Table 1).

Clearly, most of the ecologically relevant information from HPLC-derived pigment analysis is extracted at the class level of taxonomic determination (see Millie et al. 1993). If an accurate distinction of phylogenetic groups within an assemblage is desired, these results suggest that the relative contributions of taxon-specific pigments are reasonably reliable predictors of the contribution of the corresponding taxa to total phytoplankton cell numbers. Although a large amount of information can be gleaned at the class level by using HPLC pigment analyses, this method may be insufficient for understanding the finer scales of phytoplankton dynamics. For example, late in the spring bloom in the Newport estuary there were still considerable amounts of fucoxanthin present when diatom numbers were declining. The high fucoxanthin concentrations were due largely to the chrysophytes and prymnesiophytes. The contribution from diatoms should be interpreted carefully, using ancillary pigment or cell count data. Also, HPLC-based pigment analyses cannot 
Table 1. Chlorophyll a:accessory pigment ratios. fuco: fucoxanthin; 19'-hex: 19'-hexanoyloxyfucoxanthin; allo: alloxanthin; perid: peridinin

\begin{tabular}{|c|c|c|c|c|c|c|}
\hline chl a:fuco & chl $a: 19$ '-hex & chl a: allo & $\operatorname{chl} a: b$ & chl a:perid & Location & Source \\
\hline 2.31 & 1.77 & 3.04 & 6.44 & 2.69 & $\begin{array}{l}\text { Newport Estuary, N. Atlantic } \\
\left(34^{\circ} 45^{\prime} \mathrm{N}, 76^{\circ} 40 \mathrm{~W}\right)\end{array}$ & This study \\
\hline 1.47 & & 4.28 & & & $\begin{array}{l}\text { Central North Sea } \\
\left(54^{\circ} 30^{\prime} \mathrm{N}, 4^{\circ} 30^{\prime} \mathrm{E}\right)\end{array}$ & Gieskes \& Kraay (1983) \\
\hline 1.4 & 1.6 & 2.01 & 0.75 & 2.58 & $\begin{array}{l}\text { Western equatorial Pacific } \\
\left(1^{\circ} 31^{\prime} \mathrm{N}, 150^{\circ} 02^{\prime} \mathrm{E} \text { to } 13^{\circ} 27^{\prime} \mathrm{N}, 149^{\circ} 45^{\prime} \mathrm{E}\right.\end{array}$ & $\begin{array}{l}\text { Everitt et al. (1990) } \\
\text { E) }\end{array}$ \\
\hline 1.95 & 4.75 & & 7.65 & & Sargasso Sea $\left(35^{\circ} \mathrm{N}, 70^{\circ} \mathrm{W}\right)$ & Bidigare et al. (1990) \\
\hline 1.08 & 1.63 & & & & $\begin{array}{l}\text { Antarctic } \\
\left(60^{\circ} \mathrm{S} \text { to coast between } 58^{\circ} \text { and } 93^{\circ} \mathrm{E}\right)\end{array}$ & Wright \& Jeffrey (1987) \\
\hline $\begin{array}{l}1.22 \\
1.30\end{array}$ & & & & & $\begin{array}{l}\text { Lakes Kasumigaura and } \\
\text { Teganuma, Japan }\end{array}$ & Soma et al. (1993) \\
\hline
\end{tabular}

generally be used to make taxonomic distinctions within classes. A significant difference between the 2 sampling sites early in the study was the dominance of pennate and centric diatoms at Penn Point and Gallants Channel respectively (Figs, 3a, b \& $2 \mathrm{a}$, b), but pennate and centric diatoms cannot be discriminated by HPLC-based pigment analyses. Certainly, no single technique or methodology is ideal for resolving all information relevant to phytoplankton community structure and dynamics. Therefore, the role of HPLCbased pigment analyses for quantitatively assessing phytoplankton composition should be considered complementary to, but not exclusively a replacement for, microscopic enumeration.

Acknowledgements. We thank Drs Susan Huntsman and Joe Rudek for their valuable comments and Dr Gary Wickfors for kindly providing phytoplankton cultures. Dr W. Kirby-Smith generously allowed us access to his data on surface water temperatures and wind speed and direction. Paul Bates provided technical assistance. Access to the Penn Point sampling site was granted by the Hughes family and to them we extend our gratitude. This research was supported, in part, by NOAA COASTWATCH (NOAA Coastal Ocean Program), North Carolina/National Sea Grant Program, the University of North Carolina Water Resources Research Institute and the National Science Foundation and was conducted while C.G. held a National Research Council Research Associateship. Reference to trade names does not imply endorsement by either the National Marine Fisheries Service, NOAA, the University of North Carolina at Chapel Hill, or the Agricultural Research Service, USDA.

\section{LITERATURE CITED}

Bartow RG, Mantoura RFC, Gough MA, Fheman TW (1993) Pigment signatures of the phytoplankton composition in the northeastern Atlantic during the 1990 spring bloom. Deep Sea Res 40:459-477

Bidigare RR, Marra J, Dickey TD, Iturriaga R, Baker KS, Smith RC, Pak H (1990) Evidence for phytoplankton succession and chromatic adaptation in the Sargasso Sea during spring 1985. Mar Ecol Prog Ser 60:113-122
Everitt DA, Wright SW, Volkman JK, Thomas DP, Lindstrom EJ (1990) Phytoplankton community compositions in the western equatorial Pacific determined from chlorophyll and carotenoid pigment distributions. Deep Sea Res 37 975-997

Falkowski PG, Owens TG (1980) Light-shade adaptation. Plant Physiol 66:592-595

Gibbs CF (1979) Chlorophyll $b$ interference in the fluorometric determination of chlorophyll $a$ and 'phaeopigments' Aust J mar Freshwat Res 30:597-606

Gieskes WW, Kraay GW (1983) Dominance of Cryptophyceae during the phytoplankton spring bloom in the central North Sea detected by HPLC analysis of pigments. Mar Biol 75:179-185

Gieskes WW, Kraay GW (1986a) Floristic and physiological differences between the shallow and the deep nanophytoplankton community in the euphotic zone of the open tropical Atlantic revealed by HPLC analysis of pigments Mar Biol 91:567-576

Gieskes WW, Kraay GW (1986b) Analysis of phytoplankton pigments by HPLC before, during and after mass occurrence of the microflagellate Corymbellus aureus during the spring bloom in the open northern North Sea in 1983. Mar Biol 92:45-52

Goericke R, Repeta DJ (1992) The pigments of Prochlorococcus marinus: the presence of divinyl chlorophyll $a$ and $b$ in a marine procaryote. Limnol Oceanogr 37:425-433

Gowen RJ, Tett P, Wood BJB (1983) Changes in the major dihydroporphyrin plankton pigments during the spring bloom of the phytoplankton in two Scottish sea-lochs. $\mathrm{J}$ mat biol Ass UK 63:27-36

Guillard RRL, Keller MD, O’Kelly CJ, Floyd GL (1991) Pycnococcus provasoliz gen. et sp. nov., a coccoid prasinoxanthin-containing phytoplankter from the western North Atlantic and Gulf of Mexico. J Phycol 27:39-47

Guillard RRL, Murphy LS, Foss P, Liaaen-Jensen S (1985) Synechococcus spp. as likely zeaxanthin-dominant ultraphytoplankton in the north Atlantic. Limnol Oceanogr 30: $412-414$

Jeffrey SW, Sielickı M, Haxo FT (1975) Chloroplast pigment patterns in dinoflagellates. J Phycol 11:374-385

Jeffrey SW, Vesk M (1978) Effect of blue-light on the photosynthetic pigments and chloroplast structure in the marine diatom Stephanopyxis turns. Proc Aust Biochem Soc 11:94

Jennings CD, Willis JN, Lewis JM (1970) Hydrography of the Newport River estuary: a preliminary report. Cent Est 
Menhaden Res Ann Rept to AEC, July 1, 1970. NOAA, National Marine Fisheries Service, Beaufort, NC, p 66-70

Kirby-Smith WW, Costlow JD (1989) The Newport River estuarne system. Univ North Carolina Sea Grant 89-04

Klein B, Sourna A (1987) A daily study of the diatom spring bloom at Roscoff (France) in 1985. Il. Phytoplankton pigment composition studied by HPLC analysis. Mar Ecol Prog Ser 37:265-275

Lund JWG, Kipling C, LeCren ED (1958) The inverted microscope method of estimating algal numbers and the statistical basis of estimations of counting. Hydrobiologia 11 $143-170$

Mantoura RFC, Llewellyn CA (1983) The rapid determination of algal chlorophyll and carotenoid pigments and their break-down products in natural waters by reverse-phase high-performance liquid chromatography. Analyt chim Acta 151:297-314

Millie DF, Ingram DA, Dionigi CP (1990) Pigment and photosynthetic responses of Oscillatoria agardhii (Cyanophyta) to photon flux density and spectral quality. J Phycol 26: $660-666$

Millie DF, Paerl HW, Hurley JP (1993) Microalgal pigment assessments using high performance liquid chromatography: a synopsis of organismal and ecological applications. Can J Fish Aquat Sci 50:2513-2527

Naes H, Post AF (1988) Transient states of geosmin, pigments, carbohydrates and proteins in continuous cultures of Oscillatoria brevis induced by changes in nitrogen supply. Arch Microbiol 150:333-337

Paerl HW, Bland PT, Bowles ND, Haibach ME (1985) Adaptation to high-intensity, low-wavelength light among surface blooms of the cyanobacterium. Microcystis aeruginosa. Appl environ Microbiol 49:1046-1052

Paerl HW, Tucker J, Bland PT (1983) Carotenoid enhancement and its role in maintaining blue-green algal (Microcystis aeruginosa) surface blooms. Limnol Oceanogr 28: $847-857$

This article was presented by $G$. W. Thayer (Senior Editorial Advisor), Beaufort, North Carolina, USA
Parsons TR, Maita Y, Lalli CM (1984) A manual of chemical and biological methods for seawater analysis. Pergamon Press, New York

Ridout PS, Morris RJ (1985) Short-term varations in pigment composition of a spring phytoplanktan bloom from an enclosed experimental system. Mat Bicl 87:7-11

Roy S (1989) HPLC-measured chloroplyll-type pigments during a phytoplankton spring bloom in Bedford Basin (Canada). Mar Ecol Prog Ser 55:279 2c0

Sokal RR, Rohlf FJ (1969) Biometry. Freeman, San Francisco

Soma Y, Imaizumi T, Yagi K, Kasuga $S$ (1 Gig3) Estimation of algal succession in lake water using HPLC analysis of pigments. Can J Fish Aquat Sci 50:1142-1146

Thayer GW (1971) Phytoplankton production and the distribution of nutrients in a shallow unstratified estuarine system near Beaufort, NC. Chesapeake Sci 12:240-253

Trees CC, Kennicutt MC II, Brooks JM (1985) Errors associated with the standard fluorometric determination of chlorophylls and phaeopigments. Mär Chem 17:1-12

Veldhuis MJW, Kraay GW (1990) Vertical distribution and pigment composition of a picoplanktomic prochlorophyte in the subtropical North Atlantic: a combined study of HPLC analysis and flow cytometry. Mar Ecol Prog Ser 68: $121-127$

Wilhelm C, Rudolph I, Renner W (199:) A quantitative method based on HPLC-aided pigment analysis to monitor structure and dynamics of the phytoplankton assemblage - a study from Lake Meerfelder Maar IEifel, Germany). Arch Hydrobiol 123:21-35

Wright SW, Jeffrey SW (1987) Fucoxanthin pigment markers of marine phytoplankton analysed by HPLC and HPTLC. Mar Ecol Prog Ser 38:259-266

Wright SW, Jeffrey SW, Mantoura RFC, Llewellyn CA, Bjornland T, Repeta D. Welschmeyer N $\{1991$ I Improved HPLC method for the analysis of chlorophyls and carotenoids from marine phytoplankton. Mar Ecol Prog Ser 77: $183-196$

Manuscript first received: February 24, 199.

Revised version accepted: February 1, 1995 